\title{
Effet stimulant de la microflore lactique sur l'activité biochimique des bactéries propioniques
}

\author{
par \\ B. CZARNOCKA-ROCZNIAKOWA, J. JAWORSKI \\ et D. KORNACKA \\ Université d'Agriculture - Faculté de la Technologie Laitière et Alimentaire \\ et Institut de l'Industrie Laitière, Olsztyn 5 (Pologne)
}

\section{Introduction}

Les bactéries propioniques jouent un rôle important dans l'affinage des fromages à pâte dure. Leur développement abondant dans la pâte de fromage est dû à leur conjonction avec des bactéries lactiques. Il semble pourtant que l'influence de la microflore lactique sur des bactéries propioniques n'est pas tout à fait claire. D'après Lind [8], la flore lactique stimule la croissance des bactéries propioniques dans les cultures mixtes à partir de lait additionné de craie. L'auteur souligne pourtant, que Lbc. helveticus peut exercer une influence inhibitrice sur les bactéries propioniques, ce qui entraîne l'acidification rapide du milieu. Kiuri [7] a démontré que l'influence des bactéries lactiques sur la fermentation propionique pouvait varier selon les espèces de streptocoques et de lactobacilles. On observe, par exemple, l'inhibition manifeste du développement des bactéries propioniques par Str. lactis, mais pas cependant dans la culture mixte avec Lbc. casei et Str. thermophilus. Les recherches de Winkler [14] ont montré l'influence inhibitrice des souches de Lbc. lactis, Lbc. helveticus et Lbc. acidophilus sur les bactéries propioniques. Par contre, Nieuwenhof et al. [9] soulignent l'effet stimulant des lactobacilles présents dans des fromages à pâte dure.

Le problème de la conjonction des bactéries lactiques et propioniques nous a intéressés non seulement en raison des procédés d'affinage, mais aussi en vue de la possibilité d'utiliser des bactéries propioniques pour la biosynthèse de la vitamine $B_{12}$. Au cours des dernières années, on a prouvé que la fermentation propionique pouvait être utilisée avec avantage pour enrichir en cyanocobalamine certains produits laitiers, ainsi que le lactosérum destiné au fourrage. On a mis en évidence que dans le milieu où des bactéries lactiques - et surtout Str. thermophilus et des espèces du genre Lactobacillus - étaient actives, le niveau de la vitamine $\mathrm{B}_{12}$ diminuait considérablement $[1,5]$. Karlin [6] a rapporté que ces pertes 
pouvaient être compensées en introduisant des bactéries propioniques, ce qui faisait même enrichir le produit. L'auteur de ce mémoire a obtenu de bons résultats en ajoutant Propionibacterium shermanii au kéfir.

Janicki et al. [4] ont réussi, par le même procédé, à augmenter considérablement la teneur en cyanocobalamine du fromage de Tilsit, où l'affinage n'est pas normalement accompagné de la fermentation propionique.

Les possibilités d'utilisation de la fermentation propionique dans la technologie des produits laitiers étant de plus en plus considérables, l'influence de la microflore lactique sur des procédés biochimiques dus à des bactéries propioniques a une importance essentielle. L'objectif de notre travail était de rassembler des renseignements plus étendus relatifs à ce problème. En même temps, nos recherches constituent une tentative pour augmenter l'activité des bactéries propioniques en utilisant des combinaisons appropriées avec une microflore lactique.

\section{SOUCHES}

\section{Techniques expérimentales}

Dans nos études, nous avons fait usage des souches provenant de la collection de notre Institut, à l'exception des cultures de levain et des grains de kéfir qui étaient obtenus du Laboratoire des Cultures pures à Olsztyn (Pologne). Trois espèces de bactéries propioniques étaient étudiées, à savoir : Propionibacterium freudenreichii T 110, Propionibacterium shermanii T 108 et Propionibacterium petersonii $\mathrm{T} 112$. Elles étaient cultivées sur un milieu au lactosérum dont la composition était la suivante : $1000 \mathrm{ml}$ de lactosérum de présure, $10 \mathrm{~g}$ de bactopeptone Difco, $5 \mathrm{~g}$ de bactotryptone Difco, $5 \mathrm{~g}$ d'extrait de levure Difco, $1,5 \mathrm{~g} \mathrm{NaCl}$ et $15 \mathrm{mg} \mathrm{CoSO}_{4}$. Le même milieu était employé pour cultiver les bactéries lactiques, dont on préparait ensuite des filtrats privés de cellules. De tels filtrats étaient préparés à partir des cultures suivantes : Streptococcus lactis T 157, Streptococcus thermophilus T 149, Lactobacillus helveticus T 78 et des souches mixtes de streptocoques de levain. Des filtrats étaient obtenus à partir de cultures de $72 \mathrm{~h}$ à l'aide de la bougie de Berkefeld N. Ils étaient ajoutés aseptiquement à la culture des bactéries propioniques à la quantité de $10 \mathrm{p} .100(\mathrm{v} / \mathrm{v})$ qui avait été établie à la suite des essais préliminaires.

Pour les études sur l'influence de la microflore des grains de kéfir, on s'est servi du milieu suivant de composition simplifiée : $1000 \mathrm{ml}$ de lactosérum de présure, $5 \mathrm{~g}$ d'extrait de levure Difco, $1,5 \mathrm{~g} \mathrm{NaCl}$ et $15 \mathrm{mg} \mathrm{CoSO}$. Sur ce milieu, des grains de kéfir étaient cultivés à la température de $25^{\circ} \mathrm{C}$ pendant 24,48 et $72 \mathrm{~h}$. Après incubation, les grains étaient séparés à l'aide d'un tamis aux mailles de $0,6 \mathrm{~mm}$ pour obtenir un filtrat qui servait de milieu pour les cultures de bactéries propioniques. Ce filtrat contenait des strepto- 
coques vivants et des bacilles lactiques, ainsi qu'un petit nombre de levures.

\section{Cultures expérimentales}

Le milieu additionné de filtrats "privés de cellules », ou bien le lactosérum obtenu à partir de la culture des grains de kéfir, était coulé dans des fioles de $130 \mathrm{ml}$ et ensemencé de 5 p. $100(\mathrm{v} / \mathrm{v})$ de la culture de $3 \mathrm{j}$ des bactéries propioniques. La fermentation s'effectuait à $30^{\circ} \mathrm{C}$ au cours de $12 \mathrm{j}$, à $\mathrm{pH} 6,5-7,2$. Une solution saturée de soude était employée pour ajuster le $\mathrm{pH}$. Après la fermentation, la teneur en biomasse, en corrinoïdes (vitamines $\mathrm{B}_{12}$ ) et en acides volatils était déterminée.

\section{Biomasse}

La teneur en masse sèche de cellules était déterminée par la méthode pondérale. Trente $\mathrm{ml}$ de la culture étaient centrifugés à $12000 \mathrm{t} / \mathrm{mn}$ pendant $15 \mathrm{mn}$. Ensuite la biomasse était lavée et séchée à $105^{\circ} \mathrm{C}$ jusqu'à poids stable.

\section{CORRINOÏDES (VITAMINE B12 ET SES ANALOgues)}

Elles étaient libérées des cellules par chauffage avec le cyanure de potassium (Janicki et al. [3]). Elles étaient déterminées à l'aide de la souche test Escherichia coli mutans W 53 par la technique des petits cylindres décrite par Harrison et al. [2]. Les ensemencements étaient effectués sur des milieux modifiés par Tchaykovskaya et Droujinina [13]. La méthode adaptée était considérée comme un test d'ensemble pour la vitamine $\mathrm{B}_{12}$ et ses analogues.

\section{ACIDES VOLATILS}

Vingt $\mathrm{ml}$ de l'échantillon étudié étaient distillés avec la vapeur d'eau, pour obtenir $150 \mathrm{ml}$ de distillat. Le distillat était filtré et neutralisé avec $0,25 \mathrm{n} \mathrm{NaOH}$. Les acides volatils étaient libérés par la méthode de Roos et al. [11] et distribués par chromatographie en phase gazeuse, à l'aide de l'appareillage de Carlo Erba. Les résultats étaient calculés selon les surfaces des pics, en appliquant le coefficient de correction pour les indications du détecteur et les pertes qui avaient lieu au cours de la préparation d'un échantillon.

\section{Résultats}

INFLUENCE DES FILTRATS, PRIVÉS DE CELLULES, DES CULTURES DE BACTÉRIES LACTIQUES

A l'exception de la culture de Streptococcus lactis, tous les filtrats employés stimulaient l'activité des bactéries propioniques, et surtout la biosynthèse des corrinoïdes. Cet effet était fort dans les cultures de Propionibacterium freudenreichii, évident dans celles de Propionibacterium petersonii et faible dans celles de Propionibacterium shermanii (fig. 1 et 2 ). Le meilleur résultat était obtenu sur le milieu additionné de filtrats de Streptococcus thermophilus et 


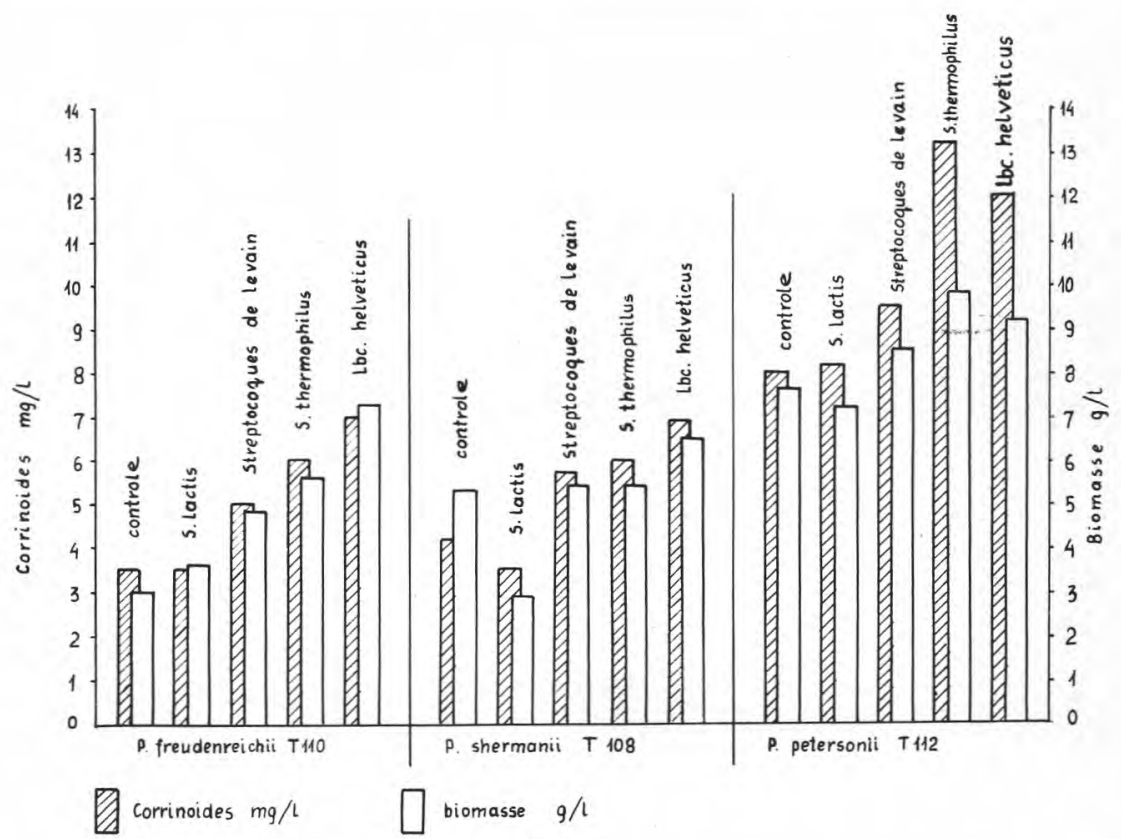

fig. 1

Influence des bactéries lactiques sur la croissance et la synthèse des corrinoïdes dans des cultures de 3 espèces de Propionibacterium

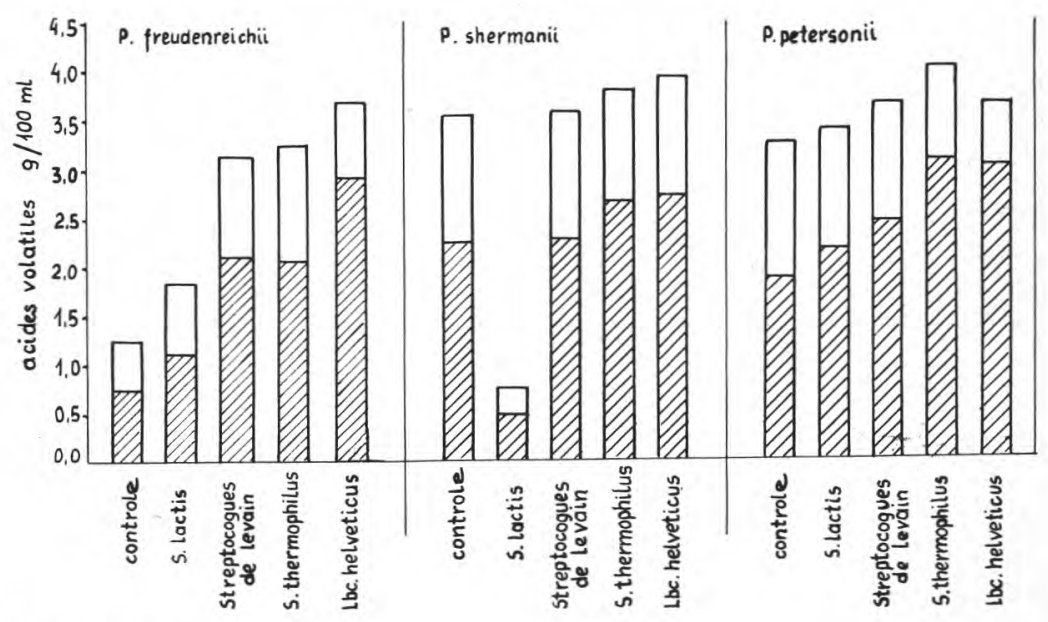

acidepropionique

$\square$ acideacétique

fig 2

Influence des bactéries lactiques sur la fermentation propionique 
Lactobacillus helveticus. L'addition de filtrat privé de cellules de la culture de Lbc helveticus faisait augmenter la récolte des germes de $P$. freudenreichii de 143 p. 100 (de 3,0 jusqu'à $7,3 \mathrm{~g}$ de masse sèche de cellules dans 1 1), tandis que la quantité des corrinoïdes synthétisés augmentait de 100 p. 100 (de 3,5 jusqu'à $7 \mathrm{mg} / \mathrm{l}$ ). On note en même temps une augmentation considérable de la teneur en acides volatils, qui montait jusqu'à 196 p. 100 (de 1,25 jusqu'à $3,7 \mathrm{mg} / \mathrm{l}$ ) et c'était surtout le pourcentage de l'acide propionique qui augmentait sensiblement (de 60 jusqu'à 79,7 p. 100).

La réaction de $P$. petersonii aux filtrats ajoutés se manifestait surtout par la biosynthèse intensifiée des corrinoïdes. Dans la culture additionnée du filtrat de $S$. thermophilus, le rendement de la biosynthèse augmentait de 65 p. 100 (de 8,0 à $13,2 \mathrm{mg} / 1$ ), et celui de Lbc. helveticus le faisait augmenter de 50 p. 100. Ces résultats présentent un intérêt, parce que cette souche se caractérisait par un rendement élevé de la biosynthèse et même dans les témoins (échantillons non additionnés de filtrats) elle donnait une teneur en corrinoïdes deux fois plus grande que celle des deux autres souches de bactéries propioniques. Quant à la teneur en acides volatils des cultures de cette souche, le filtrat de la culture de $S$. thermophilus ne la faisait augmenter que de 24 p. 100, et celui de Lbc. helveticus de 12 p. 100 . Pourtant, le pourcentage augmenté d'acide propionique, de 57,6 jusqu'à 75,6 p. 100 (Str. thermophilus) et de 57,6 jusqu'à 82,4 p. 100 (Lbc. helveticus) était aussi observé.

On a déjà mentionné que l'effet stimulant des filtrats sur la souche de $P$. shermanii était le plus faible. Pourtant, le filtrat de la culture de Lbc. helveticus, dont l'action était la plus forte, en faisait augmenter la teneur en corrinoïdes d'une manière évidente (de 64 p. 100). La récolte des germes en augmentait de 22,6 p. 100, tandis que la teneur en acides volatils ne s'élevait que de 11,8 p. 100, sans qu'une différence essentielle fût constatée dans leur pourcentage.

Le filtrat qu'on avait obtenu de la culture mixte des streptocoques de levain (S. lactis, S. cremoris, S. diacetilactis, Leuconostoc dextranicum) ne stimulait que bien faiblement l'activité de $P$. freudenreichii et $P$. petersonii, son influence sur $P$. shermanii se limitant à faire augmenter la biosynthèse de la vitamine $B_{12}$. Le filtrat privé de cellules à partir de la culture de Str. lactis différait des autres par son activité ; il inhibait fortement la croissance et l'activité biochimique de $P$. shermanii, en faisant diminuer la teneur en extrait sec de cellules de 45,3 p.100, des corrinoïdes synthétisés de 16,7 p. 100 et des produits de la fermentation même de 77,5 p. 100, sans influencer pratiquement les deux autres souches.

Pour compléter ces études, on a fait des essais avec des filtrats pasteurisés $\left(80^{\circ} \mathrm{C} / 20 \mathrm{mn}\right)$ des cultures Str. thermophilus et $L b c$. helveticus. On a démontré que le chauffage des filtrats privés de cellules en réduisait considérablement l'action stimulante (tab. 1). 


\section{INFLUENCE DE LA MICROFLORE DES GRAINS DE KÉFIR}

La souche de $P$. petersonii $\mathrm{T} 112$ qui se caractérisait par le rendement élevé de la biosynthèse des corrinoïdes, a été choisie pour des études sur l'influence de la microflore des grains de kéfir. Les grains étaient cultivés sur lactosérum, et le filtrat qui restait après leur séparation servait, après neutralisation, de milieu pour la souche étudiée. Ce filtrat contenait des streptocoques vivants et des lactobacilles avec un petit nombre de levures. Il ne montrait que des traces de vitamine $B_{12}$, et une teneur basse en acides volatils, avec la prépondérance considérable de l'acide acétique. La culture de $P$. petersonii préparée sur lactosérum non fermenté précédemment par des grains de kéfir servait de témoin.

On a montré un grand effet stimulant de la part du filtrat qui était obtenu de la culture des grains de kéfir de $24 \mathrm{~h}$. Il faisait plus que doubler la teneur en corrinoïdes synthétisés (124 p. 100), de même que celle en acides volatils, sans qu'une différence en pourcentage des acides fût constatée (tab. 2). Ici, il convient d'expliquer que la teneur relativement basse en corrinoïdes du témoin, était due à l'emploi de lactosérum non additionné de peptone. Le milieu de lactosérum enrichi de peptone n'était appliqué que dans des essais précédents sur l'effet des filtrats dépourvus de cellules de bactéries lactiques, ce qui était nécessaire pour assurer de bonnes conditions de développement aussi bien pour les streptocoques et les lactobacilles que pour les bactéries propioniques.

L'allongement du temps de culture des grains de kéfir au-delà de 24 h n'entraînait pas de différences essentielles dans la quantité des corrinoïdes synthétisés ; pourtant, il faisait diminuer la teneur en acides volatils et le pourcentage d'acide propionique, ce qui était

\section{TABLEAU 1}

Influence de la pasteurisation sur les propriétés stimulantes des filtrats dépourvus des cellules (souche de Propionibacterium petersonii)

\begin{tabular}{|c|c|c|c|}
\hline & & $\begin{array}{l}\text { Corrinoïdes } \\
\mathrm{mg} / 1\end{array}$ & $\begin{array}{c}\text { Biomasse } \\
\mathrm{g} / 1\end{array}$ \\
\hline & Milieu de lactosérum sans filtrat & 6,30 & 6,40 \\
\hline 1) & $\begin{array}{l}\text { Milieu de lactosérum avec filtrat } \\
\text { de Lactobacillus helveticus: } \\
\text { Filtrat non pasteurisé } \\
\text { Filtrat pasteurisé } 80^{\circ} \mathrm{C} / 20 \mathrm{mn}\end{array}$ & $\begin{array}{l}8,50 \\
6,03\end{array}$ & $\begin{array}{l}7,01 \\
6,83\end{array}$ \\
\hline 2) & $\begin{array}{l}\text { Milieu de lactosérum avec filtrat } \\
\text { de Streptococcus thermophilus: } \\
\text { Filtrat non pasteurisé } \\
\text { Filtrat pasteurisé } 80^{\circ} \mathrm{C} / 20 \mathrm{mn}\end{array}$ & $\begin{array}{r}11,50 \\
8,73\end{array}$ & $\begin{array}{l}8,04 \\
7,29\end{array}$ \\
\hline
\end{tabular}




\section{TABLEAU 2}

Influence de la microflore des grains de kéfir sur l'activité biochimique de Propionibacterium petersonii

\begin{tabular}{|c|c|c|c|c|c|}
\hline & & \multicolumn{3}{|c|}{ Fermentation } & \multirow{3}{*}{$\begin{array}{c}\text { Corrinoïdes } \\
\mathrm{mg} / \mathrm{l}\end{array}$} \\
\hline & & \multirow{2}{*}{$\begin{array}{c}\text { Acides } \\
\text { volatils } \\
\text { ml } 0,25 \mathrm{n} \\
\mathrm{NaOH} / 20 \mathrm{ml}\end{array}$} & \multicolumn{2}{|c|}{ Pourcentage d'acides } & \\
\hline & & & Propionique & Acétique & \\
\hline 1) & $\begin{array}{l}\text { Témoin : milieu de lacto- } \\
\text { sérum non fermenté }\end{array}$ & 14,5 & 80,9 & 19,1 & 4,1 \\
\hline 2) & $\begin{array}{l}\text { Filtrat de culture de } 1 \mathrm{j} \\
\text { des grains de kéfir }\end{array}$ & 36,5 & 80,8 & 19,2 & 9,2 \\
\hline 3) & Filtrat de culture de $2 \mathrm{j}$ & 25,4 & 79,0 & 21,0 & 10,2 \\
\hline 4) & Filtrat de culture de $3 \mathrm{j}$ & 19,8 & 75,7 & 24,3 & 11,8 \\
\hline 5) & $\begin{array}{l}\text { Filtrat de } 1 \mathrm{j} \text {, pasteurisé } \\
80^{\circ} \mathrm{C} / 5 \mathrm{mn}\end{array}$ & 18,5 & 78,6 & 21,4 & 6,6 \\
\hline 6) & $\begin{array}{l}\text { Filtrat pasteurisé } \\
80^{\circ} \mathrm{C} / 20 \mathrm{mn}\end{array}$ & 16,9 & 67,1 & 32,9 & 4,3 \\
\hline
\end{tabular}

probablement dû à l'accumulation de l'acide acétique au cours de la propagation des grains de kéfir qui précédait la fermentation propionique. Outre cela, on a constaté que le chauffage d'un filtrat influençait son effet stimulant d'une manière évidente. Le chauffage de courte durée $\left(80^{\circ} \mathrm{C}\right.$ pendant $\left.5 \mathrm{mn}\right)$ réduisait cet effet considérablement, tandis que le chauffage prolongé le supprimait presque complètement. A partir du chauffage à $80^{\circ} \mathrm{C}$ pendant $20 \mathrm{mn}$, la teneur obtenue en corrinoïdes et en acides volatils égalait à peu près celle du témoin, qui ne contenait pas de grains de kéfir.

\section{Discussion}

On a montré l'effet évident de la microflore lactique sur l'activité enzymatique des bactéries propioniques. Dans la plupart des cas, les streptocoques et les lactobacilles - surtout les espèces thermophiles de Streptococcus thermophilus et Lactobacillus helveticus stimulent la fermentation propionique, en augmentant la teneur en acides volatils et en changeant leur pourcentage à l'avantage de l'acide propionique. L'effet stimulant de la microflore lactique sur les processus intracellulaires de la biosynthèse des vitamines $\mathrm{B}_{12}$ est aussi évident.

L'intensité des phénomènes observés dépend sans doute des propriétés des espèces et des souches appartenant aux deux groupes 
de bactéries. La réaction des espèces du genre Propionibacterium, qui étaient employées dans ces études, sur les changements du milieu dus au développement de la microflore lactique, était très variée. Les différences entre les espèces ou les souches paraissent être la cause principale de la grande variation qu'on trouve dans les résultats rapportés dans la littérature.

L'inhibition des bactéries propioniques par Streptococcus lactis rapporté par Kiuri [7] n'a été confirmée que pour la culture d'une seule des trois espèces étudiées. Le fort effet inhibitif du filtrat dépourvu de cellules de Str. lactis sur l'activité de P. shermanii T 108 que nous avons observé, avait peut-être quelque rapport avec la sensibilité de cette souche à la nisine. L'explication de ce problème demande des études particulières.

Il apparaît que la nature du système métabiotique des bactéries lactiques et propioniques est encore à expliquer. En général on admet que le développement des streptocoques et des lactobacilles fait accumuler dans la pâte du fromage des lactates qui constituent pour les bactéries propioniques une source du carbone plus assimilable que le lactose. Nos recherches ont montré que c'était un autre facteur qui y jouait un rôle important, ou peut-être même décisif. C'est l'effet des petites quantités de filtrats dépourvus de cellules et le caractère thermolabile du facteur stimulant qui l'indiquent. L'action stimulante de la microflore des grains de kéfir ne peut pas être expliquée, elle non plus, par l'accumulation de l'acide lactique dans le lactosérum. Le facteur thermolabile qui est produit par la microflore du kéfir et qui stimule les bactéries propioniques peut être l'effet de l'action synergétique des bactéries lactiques et des levures.

Aucune corrélation exacte n'a été constatée entre la récolte des germes, la quantité des corrinoïdes synthétisés et la production des acides. En général, la biosynthèse des corrinoïdes était stimulée à un degré plus élevé que ne l'était la production de la masse de cellules. Cette absence de corrélation entre la croissance des bactéries propioniques et la synthèse des corrinoïdes a été déjà notée par Pedziwilk [10].

Les résultats des études sur l'influence de la microflore du kéfir peuvent avoir une valeur pratique. Les grains de kéfir constituent une riche source de protéines et de vitamines du groupe B, et les méthodes pour produire la biomasse sur milieu de lactosérum sont bien connues (Siman [12]). Pourtant, leur production comme produit principal n'est pas rentable à cause d'un rendement bien bas et de l'utilisation fort insuffisante des composants de l'extrait sec de lactosérum. En prenant pour base nos recherches, il paraît possible de produire en même temps la biomasse des grains de kéfir et le lactosérum transformé avec une teneur élevée en vitamine $B_{12 .}$. 


\section{Rés u m é}

Trois espèces de bactéries propioniques ont été cultivées sur milieu de lactosérum additionné de filtrats dépourvus de cellules des cultures de streptocoques et de lactobacilles. Outre cela, on a préparé des cultures sur des filtrats contenant des cellules vivantes qu'on avait obtenues par la propagation de grains de kéfir sur lactosérum. Dans ces cultures, la teneur en biomasse, en corrinoïdes (vitamines $\mathrm{B}_{12}$ ) et en acides volatils a été déterminé.

Les souches de Lactobacillus helveticus et de Streptococcus thermophilus stimulent l'activité des bactéries propioniques en faisant augmenter le rendement en biomasse, en vitamines $\mathrm{B}_{12}$ et en acides volatils, et surtout celui en acide propionique. Un effet moins évident est manifesté par des cultures mixtes de streptocoques de levain. En certains cas, le filtrat de culture de Streptococcus lactis inhibe la fermentation propionique.

Un fort effet stimulant sur la biosynthèse des corrinoïdes et la production des acides volatils est exercé par des filtrats de la culture de grains de kéfir. Le chauffage des filtrats en affaiblit l'effet stimulant sur les bactéries propioniques, ou bien le supprime complètement.

\section{S u $\mathbf{m} \mathbf{m}$ a r y}

Stimulating effect of lactic acid microflora on biochemical activity of propionic acid bacteria

Three species of propionic acid bacteria were cultivated on whey medium to which cellfree filtrates of streptococcus and lactobacillus cultures were added. Besides other cultures were prepared on filtrates which contained living cells and had been obtained by propagation of kefir grains on whey. The cultures were assayed on biomass, corrinoid (vitamins $\mathbf{B}_{12}$ ) and volatile acid contents.

The strains of Lactobacillus helveticus and Streptococcus thermophilus were found to stimulate propionic acid bacteria, as indicated by the increased production of biomass, vitamins $B_{12}$ and volatile acids, and especially that of propionic acid. Lees effect was shown by mixed-strain starter cultures of streptococci, and in some cases, the propionic fermentation was inhibited by the Streptococcus lactis culture filtrate.

The filtrates of kefir grain cultures showed a strong stimulatory effect on corrinoide biosynthesis and volatile acid production. The stimulatory action of filtrates could be reduced or even completely eliminated by heat treatment. 


\section{Références bibliographiques}

[1] Czarnocka-Roczniakowa (B.) et Czarnocki (J.) (1971). - L'aptitude à utiliser la vitamine $B_{12}$ par des bactéries de la fermentation lactique. Ann. Nutr. Alim., 25, 91.

[2] Harrison (G. F.) LeEs (K. A.) and Woon (F.) (1951). - The Assay of Vita. $\min \mathrm{B}_{12}$. Analyst, 44, 2651.

[3] Janicki (J.), Pawelkiewicz (J.), Stawicki (S.) et Zodrow (K.) (1953). Oznaczanie witaminy $B_{12}$ przy pomocy Euglena gracilis. Przem. Chem., 9, 614.

[4] Janicki (J.), Pedziwilk (F.) und Kisza (J.) (1963). - Die Anwedung einiger Arten bzw. Stämme von Propionisäurebakterien zur Herstellung bestimmter Käsesorten mit hohen Vitamin $\mathrm{B}_{12}$ - Gehalt. Die Nährung., 7, 406.

[5] KaRLIN (R.) (1964). - Zmeny obsahu vitaminu $B_{12}$ vo fermentovanych mliekach a moznosti zrysenia jeho obsahu pomocou Propionibacterium shermanii. Prum. Potravin., 15, 529.

[6] Karlin (R.) (1966). - Sur la teneur en vitamines du groupe B du kefir et sur son enrichissement en vitamine $\mathbf{B}_{12}$ par l'adjonction du Propionibacterium shermanii. Ann. Nutr. Alim., 20, 103.

[7] KruRu (V. J. T.) (1949). - Uber die Propionsäuregärung in Bezug auf Emmentalerkäse. Suomalaisen Tiedeakademian Toimituksia. Serien A. II Chemie, 35. Helsinki. Ref. Manuale Lactis II. Kl 56, nr 305 (1955).

[8] LiNd (C.) (1944). - Studium über Propionsäurebakterien und Demonstration der Ursachen der Käseblähung, sowie Bestimmung der flüchtifen Säuren. Beretn. Forsögm., Kbh., nr 44. Ref. D. S. A., 11, 153 (1949).

[9] NieuwenhoF (F. F. J.), Stadhouders (J.) and Hup (G.) (1969). - Effect of Lactobacilli on the Growth of Propionibacteria in Cheese. Neth. Milk Dairy J., 23, 287.

[10] Pedziwilk (F.) (1962). - Biosynteza witaminy B $_{12}$ przez bakterie kwasu propionowego. Pozn.Tow.Przyj.Nauk.Prace Komisji Nauk Roln., 2, 141.

[11] Roos (J. B.), Versnel (G. A.) und Werdmüller (T.) (1963). - Die gaschromatc graphische Bestimmung der niederen Fettsäuren von Milchfett und deren Anwendung zum Nachweis von Friemdfetten. Kiler Milchwirt. Forschungsberichte, $15,515$.

[12] Siman (J.) Zuzitkovani syrovatky (1950). - Prum. Vydavatelsvi. Praha, p. 97.

[13] Tсhaykovskaya (T.M.) et Droujinina (E. N.) (1957). - Ouprochtchennyi tchachetchnyi method opredelenya concentrasyi vitamina $\mathbf{B}_{12}$. Mikrobiol., 26, 609 .

[14] WiNKLER (S.) (1953). - Uber antibiotische Wirkungen von Lactobacillen auf Propionsäurebakterien. Int. Mlichw. Kongr., 3, 1164. 